\title{
IMPROVEMENT OF PHYSICS ACTIVITIES AND LEARNING OUTCOMES THROUGH NUMBERED HEADS TOGETHER COOPERATIVE LEARNING IN CLASS XI MIPA SMA 2 TEMBILAHAN
}

\author{
Yasni $^{*}$ \\ SMA Negeri 2 Tembilahan \\ e-mail: yasni_veri@yahoo.co.id
}

\begin{abstract}
The quality of learning in the classroom is stated to be good if the learning objectives are achieved which is marked by increased student activity and learning outcomes. For that, we need alternative learning strategies that are more effective and efficient, one of which is to use the cooperative learning model type Numbered Heads Together (NHT). This study aims to improve the activity and learning outcomes of physics on wave material through the application of the NHT learning model. The research subjects were students of class XI MIPA 3 of SMA Negeri 2 Tembilahan. This research is a classroom action research conducted in 2 cycles. Data collection instruments used were activity observation sheets and written tests of learning outcomes in the form of daily tests with data collection techniques in the form of observations and giving the test. The data analysis technique used is descriptive analysis to determine the extent of increased student activity and learning outcomes by applying the NHT learning model. The results of data analysis obtained an increase in student learning activities in the first cycle from $29.60 \%$ increased to $66.40 \%$ in the second cycle with a very good category. Improved learning outcomes from 12 students completed with a percentage of $48.00 \%$ in the first cycle, to 19 students who completed the second cycle with a percentage of 76.00\%. Thus it can be concluded that the use of the NHT learning model can improve the activities and physics learning outcomes of students of class XI MIPA $A_{3}$ in SMA Negeri 2 Tembilahan on wave material.
\end{abstract}

Keywords: student activities, physics learning outcomes, Numbered Heads Together. 


\title{
PENINGKATAN AKTIVITAS DAN HASIL BELAJAR FISIKA MELALUI PEMBELAJARAN KOOPERATIF NUMBERED HEADS TOGETHER DI

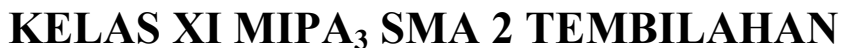

\author{
Yasni $^{*}$ \\ SMA Negeri 2 Tembilahan
}

\begin{abstract}
Abstrak
Kualitas pembelajaran di kelas dinyatakan baik apabila tujuan pembelajaran tercapai yang ditandai dengan meningkatnya aktivitas dan hasil belajar siswa. Untuk itu perlu alternatif strategi pembelajaran yang lebih efektif dan efisien, yang salah satunya adalah dengan menggunakan model pembelajaran kooperatif tipe Numbered Heads Together (NHT). Penelitian ini bertujuan untuk meningkatkan aktivitas dan hasil belajar fisika pada materi gelombang melalui penerapan model pembelajaran NHT. Subjek penelitian adalah siswa

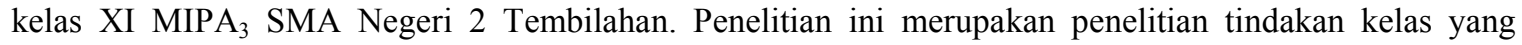
dilakukan dalam 2 siklus. Instrumen pengumpulan data yang digunakan adalah lembar observasi aktivitas dan tes tertulis hasil belajar dalam bentuk ulangan harian dengan teknik pengumpulan data berupa observasi dan pemberian tes. Teknik analisis data yang digunakan adalah analisis deskriptif untuk mengetahui sejauh mana peningkatan aktivitas dan hasil belajar siswa dengan penerapan model pembelajaran NHT. Hasil analisis data diperoleh peningkatan aktivitas belajar siswa pada siklus I dari 29,60\% meningkat menjadi $66,40 \%$ pada siklus II dengan kategori amat baik. Peningkatan hasil belajar yaitu dari 12 orang siswa tuntas dengan persentase $48,00 \%$ pada siklus I, menjadi 19 orang siswa yang tuntas pada siklus II dengan persentase $76,00 \%$. Dengan demikian dapat disimpulkan bahwa penggunaan model pembelajaran NHT dapat meningkatkan aktivitas dan hasil belajar fisika siswa kelas XI MIPA ${ }_{3}$ di SMA Negeri 2 Tembilahan pada materi gelombang.
\end{abstract}

Kata kunci : aktivitas siswa, hasil belajar fisika, Numbered Heads Together.

\section{Pendahuluan}

Pendidikan pada dasamya adalah suatu usaha sadar untuk membekali individu agar dapat mengembangkan potensi yang dimilikinya dan dapat menghadapi persaingan hidup yang semakin ketat. Salah satu alternatif usaha tersebut adalah dengan peningkatan mutu pendidikan di sekolah baik pada diri siswa maupun pada diri guru sebagai tenaga pendidik. Kualitas pembelajaran di kelas dinyatakan baik apabila tujuan pembelajaran yang telah ditetapkan tercapai, yang ditandai dengan meningkatnya hasil belajar siswa.

Belajar sangat memerlukan adanya aktivitas dari pembelajar. Pada proses aktivitas pembelajaran harus melibatkan seluruh aspek siswa baik jasmani maupun rohani, sehingga perubahan perilakunya dapat berubah dengan cepat, tepat, mudah, dan benar baik berkaitan dengan aspek kognitif, afektif maupun psikomotor (Hanafiah, 2010). Aktivitas belajar adalah suatu perilaku seseorang yang selalu berusaha, bekerja atau belajar dengan sungguh-sungguh untuk mendapat kemajuan atau prestasi yang gemilang dari perubahan tingkah laku melalui pengalaman dan latihan.

Namun kenyataannya keaktifan dan hasil belajar siswa di SMA Negeri 2 Tembilahan cenderung masih sangat rendah. Hal ini disebabkan karena: 1) masih banyak siswa yang menganggap fisika sebagai pelajaran yang sangat sulit dan membosankan, sehingga cenderung untuk dihindari. 2) masih banyak siswa yang tidak mengusai perhitungan dasar matematika seperti merubah satuan, sehingga dalam mengerjakan soal fisika juga sangat sulit untuk mereka selesaikan, 3) siswa kurang aktif bertanya kepada guru tentang materi yang diajarkan, dan 4) siswa tidak serius dalam mengikuti pembelajaran, hal ini dapat dilihat dari banyaknya siswa yang bermain saat pembelajaran berlangsung, mondar mandir saat kerja kelompok, dan izin keluar kelas setiap saat.

Melalui evaluasi hasil belajar siswa di kelas XI MIPA 3 SMA Negeri 2 Tembilahan, setelah mengikuti ulangan harian pada materi 
termodinamika, ternyata masih banyak siswa yang belum mencapai nilai batas ketuntasan. Pada materi ini siswa yang mendapat nilai tuntas hanya mencapai $20,00 \%$, artinya dari 25 orang siswa yang mencapai nilai tuntas hanya 5 orang. Keadaan ini disebabkan karena kurangnya keaktifan siswa dalam proses pembelajaran. Proses pembelajaran fisika yang dilaksanakan juga masih dominan menggunakan metode ceramah, pemberian tugas dan latihan serta diskusi kelas. Hal ini disebabkan karena kondisi siswa yang sebagian besar kurang berminat pada mata pelajaran fisika dan masih kurangnya sarana prasarana sekolah yang mendukung pembelajaran yang lebih baik seperti laboratorium.

Untuk itu perlu dicari alternatif strategi pembelajaran yang lebih efektif dan efisien untuk meningkatkan prestasi belajar siswa. Strategi itu dapat dilakukan dengan menggunakan model pembelajaran yang bervariasi. Guru harus bisa memilih model pembelajaran yang tepat agar tercapai hasil yang maksimal dan pembelajaran berhasil sesuai dengan yang direncanakan (Susanti et al., 2016). Pembelajaran kooperatif tipe Numbered Heads Together (NHT) merupakan salah satu pilihan dari pemecahan masalah tersebut, karena model pembelajaran ini mampu meningkatkan aktivitas dan hasil belajar siswa.

Menurut pandangan teori kognitif Gestalt, manusia sebagai sumber dari semua kegiatan dan dia bebas membuat pilihan dalam setiap situasi. Implikasi teori Gestalt pada pengembangan pendekatan pembelajaran fisika di kelas adalah lebih menekankan pada aspek pemahaman, kemampuan berpikir, dan aktivitas siswa. Model pembelajaran yang dapat mengaktifkan siswa, menyenangkan, dan efektif ini perlu diterapkan agar dapat mencapai tujuan pembelajaran (Rusman, 2010). Salah satu model pembelajaran yang dapat diterapkan itu adalah model pembelajaran kooperatif. Pembelajaran kooperatif merupakan proses pembelajaran dimana siswa mengerjakan tugas secara bersama-sama dengan saling membantu satu sama lainnya dalam satu kelompok (Slavin, 1995). Peran guru dalam pembelajaran kooperatif tidak lagi mendominasi jalannya pembelajaran, tetapi siswa yang dituntut lebih aktif dalam kegiatan pembelajaran (Huda, 2011). Model pembelajaran kooperatif tipe Numbered Heads
Together (NHT) pertama kali dikembangkan oleh Spenser Kagen untuk melibatkan banyak siswa dalam menelaah materi yang tercakup dalam suatu pem-belajaran (Lorina, 2012). Model pembelajaran NHT merupakan tipe pembelajaran yang dirancang untuk mempengaruhi pola interaksi siswa dan memiliki tujuan untuk meningkat-kan semangat kerjasama dalam kelompok serta memberikan kesempatan kepada siswa untuk saling membagi ide-ide dan mendiskusikan jawaban yang paling tepat. Penerapan NHT memiliki empat tahap pembelajaran, yaitu: (1) penomoran, (2) pengajuan pertanyaan, (3) berpikir bersama, (4) menjawab (Sulfiani, 2016).

Berdasarkan latar belakang yang telah diuraikan, maka perlu dilakukan penelitian tindakan kelas yang menerapkan model pembelajaran kooperatif tipe NHT dengan tujuan untuk meningkatkan aktivitas dan hasil belajar fisika siswa kelas XI MIPA3 SMA Negeri 2 Tembilahan pada materi gelombang.

\section{Bahan dan Metode}

Jenis penelitian yang digunakan adalah penelitian tindakan kelas (PTK), dalam rangka memperbaiki mutu proses pembelajaran di kelas, sehingga berfokus pada proses belajar mengajar yang terjadi di kelas (Ningsih, 2016). Penelitian PTK ini terdiri dari dua siklus yang mana setiap siklusnya meliputi empat tahap yaitu tahap menyusun rancangan tindakan (planning), tahap pelaksanaan tindakan (acting), tahap pengamatan (observasi), dan tahap refleksi (reflecting) (Faizah, 2011).

Tahap perencanaan, dipersiapkan perangkat pembelajaran yang terdiri dari silabus, rencana pelaksanaan pembelajaran (RPP) serta LKS. Instrumen pengumpulan data yang terdiri dari lembar pengamatan aktivitas siswa dan lembar soal tes hasil belajar. Instrumen pengumpulan data yang digunakan berupa soal tes, kuis, lembar observasi dan catatan lapangan (Suwanto, 2018).

Tahap pelaksanaan tindakan, merupakan implementasi atau penerapan dari seluruh perencanaan kegiatan yang mengandung inovasi atau pembaharuan dalam upaya memperbaiki atau meningkatkan mutu 
pembelajaran. Siklus pertama tindakan dilakukan saat proses pembelajaran berlangsung secara teratur sesuai dengan kegiatan pembelajaran pada RPP 1 dengan menerapkan tahapan NHT. Selanjutnya pada siklus kedua, tindakan dilakukan berdasarkan hasil refleksi siklus pertama yang dituangkan dalam RPP 2 dengan pelaksanaan tindakan sesuai dengan tahapan NHT.

Pengamatan dilakukan pada waktu tindakan sedang dilaksanakan. Saat pengamatan, observer membuat catatancatatan terhadap aktivitas siswa selama proses pembelajaran berlangsung, agar diperoleh data yang akurat untuk melakukan perbaikan pada siklus berikutnya.

Tahap refleksi dilakukan ketika sudah selesai dilakukan tindakan pada setiap siklusnya. Kemudian dilakukan diskusi dengan observer mengenai implementasi rancangan tindakan, apakah sudah berjalan dengan baik dan bagian mana yang belum dari pelaksanaan siklus pertama. Kemudian dilanjutkan membuat rancangan untuk siklus kedua. Setelah siklus kedua berakhir, menyampaikan rencana yang disarankan kepada peneliti lain (Faizah, 2011).

Penelitian ini diadakan di SMA Negeri 2 Tembilahan pada semester genap Tahun Pelajaran 2018/2019 dengan subyek penelitian siswa kelas XI MIPA3 dengan jumlah siswa 25 orang, 7 orang laki-laki dan 18 orang perempuan.

Instrumen pada penelitian ini adalah instrumen pengumpulan data yang terdiri dari: 1) lembar observasi untuk mengetahui keaktifan siswa yang berisikan tentang kesiapan belajar, interaksi antar siswa dengan guru, interaksi siswa dengan guru, tanggung jawab dan percaya diri, dan 2) tes hasil belajar siswa berupa hasil post test di setiap akhir satu siklus.

Teknik analisa data yang digunakan adalah teknik analisis deskriptif, yang di gunakan untuk menganalisis sejauh mana tingkat aktivitas siswa dalam proses pembelajaran pada setiap siklus, memenuhi persamaan (1).

$$
\% \text { Aktivitas }=\frac{\text { Jumlah Skor yang diperoleh }}{\text { Jumlah Skor Maksimum }} \times 100 \%
$$

Selanjutnya dari hasil penghitungan tersebut dapat dilihat kategori aktivitas siswa berdasarkan pada Tabel 1.
Tabel 1. Kategori aktivitas siswa

\begin{tabular}{ccl}
\hline No & Persentase & \multicolumn{1}{c}{ Kategori } \\
\hline 1 & $0 \%-20 \%$ & Kurang baik \\
2 & $21 \%-40 \%$ & Kurang \\
3 & $41 \%-60 \%$ & Cukup \\
4 & $61 \%-80 \%$ & Baik \\
5 & $81 \%-100 \%$ & Sangat Baik \\
\hline
\end{tabular}

Sumber: (Trikoriantono, 2017).

Untuk mengukur ketuntasan hasil belajar siswa ditentukan dengan menggunakan persamaan (2).

Ketuntasan $(\%)=\frac{\text { Jumlah skor yang diperoleh }}{\text { Jumlah skor maksimum }} \times 100 \%$

Sedangkan untuk mengukur ketuntasan belajar secara klasikal digunakan persamaan (3).

$\%=\frac{\text { jumlah siswa yang mendapat nilai }>65}{\text { jumlah siswa seluruhnya }} \times 100 \%$

Ketuntasan belajar klasikal dinyatakan berhasil jika persentase siswa yang tuntas belajar jumlahnya lebih besar atau sama dengan $75 \%$ dari jumlah seluruh siswa di dalam kelas.

\section{Hasil dan Pembahasan}

Penelitian PTK ini dilakukan dalam rangka meningkatkan aktivitas dan hasil belajar fisika siswa SMA Negeri 2 Tembilahan dengan penerapan model Numbered Heads Together (NHT) dalam pembelajaran fisika yang pelaksanaannya mengikuti langkah-langkah NHT yaitu penomoran, pengajuan pertanyaan, berpikir bersama, dan menjawab (Pangestu \& Kadir, 2019). Adapun hasil penelitian dengan dua siklus diuraikan sebagai berikut:

\section{Siklus Pertama}

Melalui siklus pertama dilakukan sebanyak tiga kali pertemuan dengan satu kali ulangan harian. Kegiatan pembelajaran pada siklus pertama ini dilakukan pada tanggal 6 dan 7 Pebruari 2019. Sedangkan ulangan harian dilaksanakan tanggal 13 Pebruari 2019. Kegiatan pembelajaran yang telah dilakukan pada siklus pertama, direfleksi bersama observer. Hasil refleksi menunjukkan bahwa 
aktivitas belajar dan hasil tes belajar siswa belum memenuhi indikator keberhasilan yang lebih baik, karena masih terdapat beberapa kendala. Kendala tersebut adalah:

a. Rasa percaya diri siswa kurang, sehingga jarang menyampaikan pendapat pada saat diskusi dan takut untuk menjawab soal.

b. Siswa kurang mengerti terhadap contoh soal yang diberikan.

c. Interaksi siswa dengan guru saat proses pembelajaran masih rendah.

Oleh karena itu, hal-hal yang harus diperhatikan dan diperbaiki untuk pertemuan berikutnya adalah :

a. Meningkatkan rasa percaya diri siswa dengan cara memberikan motivasi dan tidak membandingkannya dengan siswa yang lain, sehingga siswa berani untuk menyampaikan pendapat pada saat diskusi dan berani menjawab soal saat ulangan.

b. Meningkatkan pemahaman siswa terhadap contoh soal yang diberikan. Hal ini dapat dilakukan dengan mengajak siswa untuk menemukan kata kunci pada soal dengan cara membaca soal secara berulang-ulang agar lebih mudah dipahami.

c. Meningkatkan interaksi siswa dengan guru. Pada saat proses pembelajaran berlangsung, guru harus bisa menempatkan dirinya sebagai teman atau mitra kerja, sehingga siswa bisa leluasa bertanya dan mengemukakan pendapat.

Untuk memperbaiki kendala yang ada pada siklus pertama, maka penelitian dilanjutkan ke siklus kedua, sehingga diharapkan siswa dapat memenuhi indikator keberhasilan.

\section{Siklus Kedua}

Siklus kedua dilakukan sebanyak tiga kali pertemuan dengan satu kali ulangan harian yang dilaksanakan pada tanggal 14 dan 20 Pebruari 2019. Sedangkan ulangan harian tanggal 21 Pebruari 2019. Pada siklus kedua ini masih tetap menerapkan langkah-langkah dan model pembelajaran NHT sesuai pada siklus pertama dengan memperhatikan kendala dan memperbaiki kekurangankekurangan berdasarkan refleksi siklus pertama. Kegiatan pembelajaran yang telah dilakukan pada siklus kedua, direfleksi oleh peneliti bersama observer. Berdasarkan analisis data yang diperoleh dari lembar pengamatan dan hasil tes selama menerapkan model pembelajaran Numbered Heads Together (NHT) menunjukkan, bahwa pada siklus kedua terlihat aktivitas dan hasil belajar siswa sudah semakin baik dan sesuai dengan perencanaan.

Melalui hasil refleksi siklus kedua dimana proses pembelajaran sudah diperbaiki sesuai hasil refleksi siklus pertama dan hasil belajar sudah mencapai indikator keberhasilan, maka peneliti dan observer sepakat bahwa penelitian dapat dihentikan.

Data hasil pengamatan aktivitas belajar siswa siklus pertama dan kedua selama proses pembelajaran berlangsung dengan menggunakan model pembelajaran Numbered Heads Together (NHT) dapat dilihat pada Tabel 2.

Tabel 2. Rekapitulsi data hasil penelitian

\begin{tabular}{lllcc}
\hline No & Aspek & Kategori & $\begin{array}{c}\text { Siklus } \\
\text { I }\end{array}$ & $\begin{array}{c}\text { Siklus } \\
\text { II }\end{array}$ \\
\hline \multirow{3}{*}{1} & \multirow{3}{*}{$\begin{array}{l}\text { Aktivitas } \\
\text { siswa }\end{array}$} & Sangat & $29,60 \%$ & $66,40 \%$ \\
& baik & & \\
& & Baik & $35,20 \%$ & $23,20 \%$ \\
& & Cukup & $35,20 \%$ & $10,40 \%$ \\
2 & Hasil & Tuntas & $48,00 \%$ & $76,00 \%$ \\
& belajar & Tidak & $52,00 \%$ & $24,00 \%$ \\
& & Tuntas & & \\
\hline
\end{tabular}

Berdasarkan Tabel 2 dapat dilihat dari siklus pertama ke siklus kedua, aktivitas siswa dengan kategori sangat baik mengalami peningkatan dari $29,60 \%$ menjadi $66,40 \%$. Sedangkan kategori baik dan cukup mengalami penurunan persentase dari $70,40 \%$ menjadi 33,60\%. Ini menunjukkan bahwa penerapan model pembelajaran Numbered Heads Together (NHT) selama proses pembelajaran dapat meningkatkan keaktifan siswa ke yang lebih baik. Pernyataan ini juga didukung oleh penelitian yang dilakukan oleh Harmini (2017) dengan hasil penelitiannya mengatakan bahwa penerapan model pembelajaran NHT dapat meningkatkan aktivitas belajar IPS pada siswa SMP Negeri 2 Ponorogo. Hasil tes belajar fisika diperoleh dari nilai yang didapat siswa setelah mengikuti tes ulangan harian pada siklus I dan siklus II dapat diketahui dari Tabel 2 dimana siswa yang tuntas mengalami peningkatan dari $48,00 \%$ menjadi $76 \%$, sedangkan yang 
tidak tuntas terjadi hal yang sebaliknya yaitu mengalami penurunan dari $52,00 \%$ menjasi $24 \%$. Selanjutnya data peningkatan aktivitas belajar siswa dapat ditunjukkan pada grafik dalam Gambar 1. Aktivitas siswa pada siklus 1 cenderung merata sebarannya, bahkan aktivitas dengan kategori sangat baik lebih sedikt, sedangkan pada siklus 2 peningkatan aktivitas lebih banyak yang berkategori sangat baik dari pada yang berkategori baik dan cukup. Hai, ini berati bahwa penerapan NHT berhasil meningkatkan aktivitas belajar siswa dalam pembelajaran Fisika pada materi gelombang.

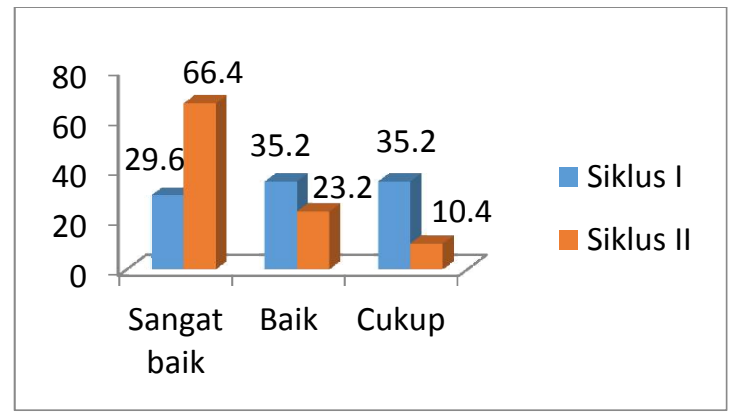

Gambar 1. Peningkatan aktivitas siswa.

Hasil analisis data terhadap hasil belajar siswa selama proses pembelajaran dengan menggunakan model pembelajaran Numbered Heads Together berdasarkan Tabel 2 dapat dilihat pada Gambar 2.

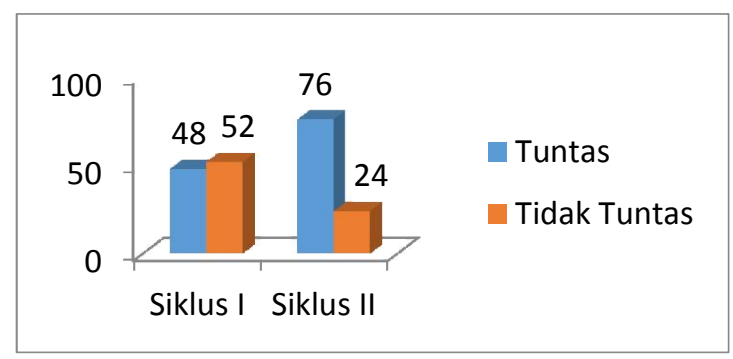

Gambar 2. Peningkatan hasil belajar siswa.

Gambar 2 menunjukkan bahwa hasil belajar siswa pada siklus 1 lebih banyak yang tidak tuntas dibandingkan yang tuntas, sedangkan pada siklus 2 terjadi perubahan dimana hasil belajar siswa lebih banyak yang tuntas dan tinggal sedikit siswa yang tidak tuntas. Artinya hasil tes belajar siswa yang mencapai KKM setiap siklus meningkat, dengan persentese ketuntasan dari 48,00\% menjadi $76,00 \%$. Hal ini juga sesuai dengan kajian yang dilakukan oleh Mahir (2016) tentang penerapan model pembelajaran kooperatif tipe Numbered Heads Together yang dapat meningkatkan hasil belajar fisika peserta didik kelas XI IPA 4 SMA Negeri 16 Makassar.

Penerapan NHT dapat meningkatkan hasil belajar karena membuat siswa lebih aktif, lebih menyenangkan, dan lebih termotivasi dalam pembelajaran. Sesuai dengan pernyataan Setyanto (2011) yang menyatakan keuntungan pembelajaran NHT yaitu: (1) dapat meningkatkan prestasi siswa dalam belajar, (2) mampu memperdalam pemahaman siswa, (3) membantu siswa dalam bekerjasama (kekompakan) dalam kelompok, (4) membantu siswa untuk meningkatkan rasa percaya diri siswa untuk berani berbicara di depan kelas (menjawab pertanyaan), (5) mengembangkan rasa ingin tahu sehingga dapat memunculkan semangat dalam diri siswa untuk dapat memahami materi dan mengetahui jawaban dari soal yang diberikan pada guru, (6) membuat suasana kelas yang menyenangkan saat belajar.

Secara umum peningkatan ini terjadi karena meningkatnya pemahaman siswa terhadap contoh soal sehingga menimbulkan rasa percaya diri yang tinggi untuk menyelesaikan soal-soal yang diberikan. Terjadinya interaksi yang baik antara guru dan siswa menyebabkan siswa merasa nyaman untuk bertanya dan mengemukakan pendapatnya saat pembelajaran berlangsung.

\section{Kesimpulan dan Saran}

Penerapan model pembelajaran Numbered Heads Together dapat meningkatkan aktivitas dan hasil belajar fisika siswa kelas XI MIPA 3 SMA Negeri 2 Tembilahan pada semester genap tahun pelajaran 2018/2019.

Model pembelajaran Numbered Heads Together merupakan model pembelajaran yang cukup efektif apabila digunakan pada materi pembelajaran yang tepat, sehingga hasil pembelajaran cukup memuaskan. Seorang guru harus memberikan motivasi untuk meningkatkan aktivitas belajar siswa, meningkatkan kerja kelompok, dan meningkatkan hasil belajar siswa supaya prestasi belajar siswa meningkat.

Saran yang dapat penulis kemukakan sehubungan dengan hasil penelitian ini adalah 
dimana guru dapat menerapkan model pembelajaran kooperatif tipe Numbered Heads Together (NHT) sebagai salah satu alternatif dalam melaksanakan proses pembelajaran di sekolah untuk meningkatkan aktivitas dan hasil belajar siswa.

\section{Daftar Pustaka}

Faizah, Hasnah. (2011). Menulis Karangan Ilmiah. Pekanbaru: Cendikia Insani.

Hanafiah, Nanang. (2010). Konsep Strategi Pembelajaran. Bandung: Refika Aditama.

Harmini, Sri. (2017). Penerapan Model Pembelajaran Numbered Heads Together untuk Meningkatkan Aktivitas Belajar dan Hasil Belajar IPS Siswa Kelas VIII G SMPN 2 Ponorogo. Gulawentah Jurnal Studi Sosial, 2(1), Juli 2017.

Huda, M. (2011). Cooperative Learning Metode, Teknik, Struktur, dan Penerapan. Yogyakarta: Pustaka Pelajar.

Lorina, Pirade. (2012). Penerapan Model Pembelajaran Kooperatif Tipe Numbered Head Together Berbantuan Media Gambar untuk Meningkatkan Hasil Belajar Siswa Pada Mata Pelajaran IPA Di Kelas IV SDN No. 1 Tanjung Padang, Palu. Universitas Tadulako. Elementary School of Education E-Journal, 2(2), Media Publikasi Ilmiah Prodi PGSD Juni 2014.

Mahir. (2016). Peningkatan Hasil Belajar Fisika Melalui Model Pembelajaran Kooperatif Tipe Numbered Heads Together Pada Peserta Didik Kelas XI IPA 4 SMA Negeri 16 Makassar. Jurnal Pendidikan Fisika Universitas Muhammadiyah Makassar, 4( 1).

Ningsih, Kurnia. (2016). Karya Tulis Ilmiah melalui Penelitian Tindakan Kelas. Materi Pelatihan Penulisan Karya Tulis Ilmiah. Disampaikan di Pontianak tanggal 16 September 2016. Universitas Tanjungpura, Pontianak.
Pangestu, Catur Budi \& Kadir. (2019). Meningkatkan Hasil Belajar Matematika Siswa Melalui Model Pembelajaran Kooperatif Tipe Numbered Head Together (NHT). ALGORITMA Journal of Mathematics Education (AJME), 1(1).

Rusman. (2010). Model-Model Pembelajaran Mengembangkan Profesional Guru. Jakarta: Raja Grasindo Persada.

Setyanto, J. (2011). Penerapan Pembelajaran Tipe Numbered Heads Together (NHT) Dengan Tugas Menulis Jurnal Belajar untuk Meningkatkan Motivasi, Keterampilan Metakognitif dan Hasil Belajar IPA Siswa Kelas VIII C SMP Negeri 1 Blitar. Tesis tidak diterbitkan. Malang:Pascasarjana Universitas Negeri Malang.

Slavin, R.E. (1995). Cooperative Learning Theory, Research and Practice. Second Edition. Boston: Allyn and Bacon.

Sulfiani, Ridha. (2016). Penerapan Model Pembelajaran Kooperatif Tipe Numbered Head Together (NHT) Untuk Meningkatkan Hasil Belajar Kimia Siswa Kelas XI IPA1 SMA Negeri 3 Watampone (Studi pada Materi Pokok Struktur Atom, Sistem Periodik Unsur dan Bentuk Molekul). Jurnal Chemica, 17 (1). Juni 2016.

Susanti, Febri., et al. (2016). Perbedaan Hasil Belajar Fisika Melalui Model Pembelajaran Kooperatif Tipe Numbered Heads Together (NHT) Berbantuan Kartu Soal dengan Model Pembelajaran Direct Instruction Di SMAN 7 Mataram Tahun Ajaran 2015/2016. FKIP Universitas Mataram. Jurnal Pendidikan Fisika dan Teknologi (JPFT), 2(4), Oktober 2016.

Suwanto. (2018). Penelitian Tindakan Kelas, Sekolah, dan Best Practice. Jawa Timur: Pustaka Intermedia.

Trikoriantono, Agus, (2017). Upaya Meningkatkan Hasil Belajar Mata Pelajaran Produktif ATPH Kelas XII dengan Model Pembelajaran Langsung di SMK Negeri 2 Tanah Grogot. Jurnal Mitra Pendidikan, 4(3), Juli 2017. 